\title{
Światy możliwe, światy fikcyjne, światy skonstruowane a proces genezy*
}

\section{Daniel Ferrer}

ORCID: 0000-0002-9455-2281
*Tekst publikujemy za zgodą Daniela Ferrera. Dziękujemy autorowi za udostępnienie tekstu. Le texte est publié avec l'accord de Daniel Ferrer. Merci à l'auteur d'avoir partagé le texte. Podstawa przekładu: Daniel Ferrer, „Mondes possibles, mondes fictionnels, mondes construits et processus de genèse", Genesis, nr 30 (2010): 109-130, http://journals.openedition.org/genesis/127

O brave new world Shakespeare, Burza

J'ai désormais [...] tous les mondes dont j'ai besoin. Zola, szkic powieści Pieniądz

W przelotnym, euforycznym uniesieniu krytyka genetyczna, zwłaszcza w dziedzinie literatury, zdała się uosobieniem, jak mówi Leibniz, „wiedzy czystego rozumu (odnoszącej się do wszystkich możliwości), w której należy ostatecznie poszukiwać źródła rzeczy” i brała pod uwagę możliwość uznania za model wielkiej konstrukcji, którą filozof umieszcza w zakończe-

${ }^{1}$ Gottfried Wilhelm Leibniz, Teodycea: o dobroci Boga, wolności człowieka i pochodzeniu zła, tłum. Małgorzata Frankiewicz i Jerzy Kopania (Warszawa: Wydawnictwo Naukowe PWN, 2001), 478. Dalsze cytaty z tego dzieła oznaczono skrótem $\mathrm{T}$ i numerem odpowiedniej strony - przyp. tłum. 


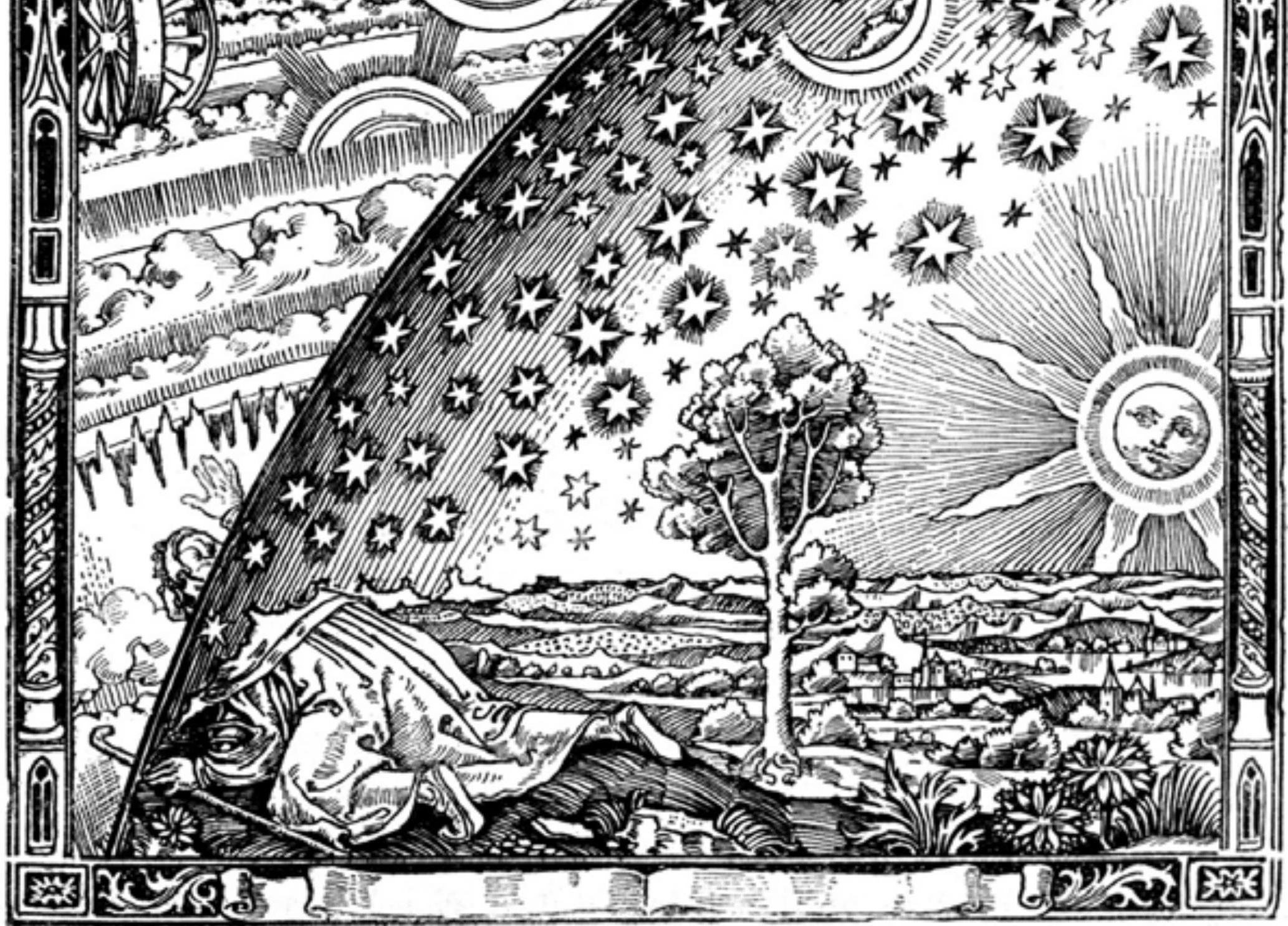

Ilustracja 1. Grawiura na drewnie nieznanego artysty zamieszczona w dziele Camille'a Flammariona L'atmosphère: météorologie populaire z 1888 roku. Podpis pod ryciną: Średniowieczny misjonarz opowiada, że odkrył punkt, w którym niebo styka się z ziemią..

niu Teodycei po to, aby oświetlić swoją koncepcję konieczności i najlepszego z możliwych światów (tę, z której naśmiewa się Voltaire w Kandydzie). Stworzenie czegoś „o niepojętym blasku i niezmierzonym ogromie" zostaje podkreślone przejściem serii nakładających się na siebie progów (dialog wprowadzający do baśni, w której wyrocznia kieruje podróżą i sprowadza sen), zanim zostanie przedstawione przez samą boginię Atenę:

Widzisz tutaj Pałac Przeznaczeń, którego strzegę. Są w nim obrazy nie tylko tego, co się zdarza, lecz także wszystkiego, co jest możliwe, a gdy Jowisz dokonał ich przeglądu przed początkiem istniejącego świata, poprzydzielał możliwości do światów i wybrał najlepszy ze wszystkich. Niekiedy przybywa odwiedzić te strony, aby z przyjemnością jeszcze raz podsumowywać sprawy i odnawiać własny wybór, który na pewno go zadowala. Jeżeli wypowiem słowo, zobaczymy cały świat, który mój ojciec mógł stworzyć i w którym będzie przedstawione wszystko, czego można zapragnąć. Dzięki temu zdołamy dowiedzieć się ponadto, co by zaszło, gdyby taka czy inna możliwość miała zaistnieć. (T, s. 475)

Ta przyprawiająca o zawrót głowy budowla składa się z nieskończonej liczby komnat, z których każda odpowiada jakiemuś światu alternatywnemu. Przejście przez jedną z nich pozwala widzieć życie jak „w mgnieniu oka podczas teatralnego przedstawienia”. Każda komnata zawiera skądinąd „wielką zapisaną księgę” opowiadającą „historię tego świata [...]: oto księga jego przeznaczeń”. Wystarczy przejść „do innej komnaty, gdzie jest inny świat, inna księga”, inne przeznaczenie. 
Komnaty układały się w piramidę, w miarę pod-chodzenia ku wierzchołkowi stawały się coraz piękniejsze i ukazywały piękniejsze światy. Wreszcie doszli do najwyższej komnaty, która zamykała piramidę i była najpiękniejsza ze wszystkich. Piramida miała bowiem początek, ale nie było widać jej końca, miała wierzchołek, ale nie miała podstawy i rozrastała się w nieskończoność. „Jest tak dlatego” [...] „że wśród niezliczonej wielości możliwych światów znajduje się najlepszy ze wszystkich. W przeciwnym razie Bóg nie zdołałby zdecydować się na stworzenie żadnego z nich. Ale nie ma żadnego świata, pod którym nie znajdowałby się jeszcze mniej doskonały od niego...”. (T, s. 477)

Jowisz Leibniza jest zarazem twórcą dzieła i archiwistą własnej twórczości. Ewaluacja tego dzieła tłumaczy się w kategoriach estetycznych: najlepszym z możliwych światów jest ten „najpiękniejszy z wszystkich” i to on wciela się w najpiękniejszą reprezentację. Podobnie jak w wypadku genezy artystycznej czy literackiej perfekcja jest w istocie relatywna: jedna wersja przewyższa inną, ponieważ jest od niej lepsza, ale ona sama zostaje zdetronizowana przez inną, która jest najlepsza, po to aby można dokonać wyboru, który z punktu widzenia twórcy przedstawia najlepszy z możliwych kompromisów. Perfekcja absolutna nie pochodzi z tego świata ani z żadnego świata możliwego dla absolutnej inteligencji. Ale Jowisz jest także autogenetykiem, który pochyla się nad swoim własnym przed-tekstem i czyni zeń majestatyczny pomnik, podstawę ukończonego dzieła. Ten układ przypomina edycję krytyczną zaopatrzoną w apendyks genetyczny, w którym skolacjonowano całość przed-tekstu². Perspektywa Jowisza, który „niekiedy przybywa odwiedzić te strony, aby z przyjemnością jeszcze raz podsumowywać sprawy i odnawiać własny wybór, który na pewno go zadowala”, oraz perspektywa gościa, przechodzącego przez nakładające się na siebie komnaty i porównującego je do świata, który rzeczywiście został stworzony, są podobne do perspektywy krytyki genetycznej, która z retrospektywnego punktu widzenia rozważa ukończone dzieło i zbiór wersji tego dzieła.

Mówienie o odwiedzaniu miejsc, przemierzaniu komnat, rekapitulacji jest umieszczaniem genetycznego dochodzenia poza idealną równoczesnością, w wymiarze czasowym - ten wymiar jest za to całkowicie nieobecny w samej kreacji. Jak się ostatecznie okazuje, twórczość jowiszowo-leibnizowska zawsze już była, nigdy się nie rozwija, w całości sprowadza się do punktu źródłowego. Wyklucza ona możliwość endogenicznego czy egzogenicznego przypadku³ który miałby niespodziewanie zmienić bieg kreacji: wszystko jest przewidziane, dokonane, zanim jeszcze zostało rozpoczęte. Ten przed-tekst wyklucza wszelką chronologię, jego wersje są dane jako współobecne, zhierarchizowane w funkcji systemu ustalonych uprzednio i niezmiennych wartości (skoro Jowisz „nie mógł nie wybrać tego świata, który przewyższa doskonałością wszystkie inne i stanowi wierzchołek piramidy"). Jeśli chodziłoby o jakąś edycję, to jasne jest, że nie byłaby ona edycją genetyczną ani nie stanowiłaby, nawet biorąc pod uwagę pełny zbiór wersji, radykalnego zaprzeczenia procesu genetycznego.

Czy oznacza to, że z takiego modelu nie da się niczego zachować? Pojęcie „światów możliwych", tak błyskotliwie wprowadzone przez Leibniza, było źródłem wielu inspiracji: pisarze

\footnotetext{
${ }^{2}$ Można by tu mówić o edycji hipermedialnej, o wirtualnej rzeczywistości wzbogaconej linkami odsyłającymi do tekstu, w której proste kliknięcie pozwala przejść do reprezentacji wizualnej („Połóż palec na dowolnej linii [...] a naprawdę ujrzysz przedstawione dokładnie to, co z grubsza wyraża owa linia”, T, s. 477).

${ }^{3}$ Zob. Daniel Ferrer, „L'écriture et l'accident”, w Critique génétique: concepts, méthodes, outils, red. Olga Anokhina i Sabine Pétillon (Paris: IMEC éditeur, 2009; seria „Inventaires”), 5-19.
} 
science-fiction, filozofowie, logicy... Dająca wiele różnych możliwości idea, dzięki zestawieniu światów, zdaje się w szczególny sposób, intuicyjnie zaadaptowana do badań genetycznych, w których nie jest jednak pojmowana w trybie statycznym. Istnieje więc pokusa zwrócenia się ku „semantyce światów możliwych”, którą logicy wypracowali w XX wieku na podstawie wizji Leibniza, ale w perspektywie wyraźnie odmiennej. Spróbujmy podjąć tę ideę, która z konieczności będzie uproszczona, a nawet spłycona, po to aby zobaczyć, czy krytyka genetyczna mogłaby się nią w jakiś sposób zainspirować ${ }^{4}$.

\section{Logika modalna i światy możliwe}

Tradycyjna logika od dawna rozwijała zbiór procedur, które pozwalały jej ocenić wartość twierdzeń, ale nie wie ona zbyt dobrze, w jaki sposób traktować twierdzenia „zmodalizowane”, które zawierają cechę możliwości czy konieczności („możliwe, że któregoś dnia odnajdziemy rękopis Armance”, „konieczne jest, aby dzieło miało swój początek”), postawy propozycjonalne („Wierzę, że dwa i dwa mogą dać pięć”, „wyobrażam sobie, że mógł przyjść”) czy też zdania zwane „kontrfaktycznymi” ("gdyby kangury nie miały ogonów, przewracałyby się do przodu”, "gdyby Joyce był mniej krótkowzroczny, zostałby raczej malarzem, a nie pisarzem”, „gdybym się odwrócił, to bym widział"), które opisują stany rzeczy nieodpowiadające rzeczywistości.

Logiczne podejście do takich twierdzeń wynika z logiki modalnej. Semantyka światów możliwych została wynaleziona $w$ jej ramach po to, aby rozwiązać trudności intensjonalne, przenosząc je na plan ekstensjonalny, to znaczy przekształcając problemy, które wyłaniają się ze znaczenia twierdzeń, na problemy referencji. Ściślej mówiąc, chodzi o wcielenie modalności do światów postulowanych (świat, z którego wyłania się rękopis Armance, świat moich przekonań, świat kangurów bez ogona...). W takim kontekście można powiedzieć, że twierdzenie jest możliwe, jeśli istnieje co najmniej jakiś jeden świat dostępny ze świata rzeczywistego, w którym to twierdzenie jest prawdziwe, podczas gdy twierdzenie jest konieczne, jeśli jest prawdziwe we wszystkich światach dostępnych ze świata rzeczywistego.

W ten sposób zdefiniowany abstrakcyjnie jest zbiór grawitujących wokół siebie światów, regulowanych przez pojęcie „dostępności”. Wszystko zależy od tego, co obejmuje ta nazwa. Najprościej jest uznać za dostępny ze świata rzeczywistego każdy świat podporządkowany prawu niesprzeczności i zdefiniować te światy jako możliwe. Ale świat, w którym żyjemy, niekoniecznie będzie światem wybranego odniesienia i nic nie stoi na przeszkodzie zdefiniowania bardziej złożonych reguł dostępności (do czego jeszcze wrócimy).

W statusie ontologicznym, nadanym przez filozofów tym wyobrażonym przez logikę światom, istnieje wiele przeciwstawnych koncepcji, wśród których można wskazać trzy główne linie. Najbardziej rozpowszechniona i odpowiadająca zdrowemu rozsądkowi jest - często zali-

\footnotetext{
${ }^{4}$ Sugerowałem taką możliwość w: „La toque de Clementis: rétroaction et rémanence dans les processus génétiques”, Genesis, nr 6 (1994), 93-106, a potem jeszcze dobitniej w „Le matériel et le virtuel: du paradigme indiciaire à la logique des mondes possibles”, w Pourquoi la critique génétique? Méthodes, théories, red. Michel Contat i Daniel Ferrer (Paris: CNRS Éditions, 1998), 11-30. Moje sugestie zostały rozwinięte w niniejszym artykule, nadal w sposób programowy.
} 
czana do „realizmu umiarkowanego” - idea, zgodnie z którą możliwość stanowi część rzeczywistości, a światy możliwe są nieoddzielone od świata rzeczywistego, do którego należą z różnych racji, tworów myślowych lub potencjalności logicznych. Na drugim miejscu znajduje się koncepcja „antyrealizmu”, która przeczy znaczeniu światów możliwych, a nawet - w wypadku Goodmana - dekonstruuje pojęcie możliwości ${ }^{5}$. W tej perspektywie dysponujemy jedynie wersjami świata i nie możemy powiedzieć, że któraś z nich odpowiada rzeczywistości niezależnej od wszystkich wersji ${ }^{6}$. Wreszcie koncepcja całkowicie przeciwstawna broni radykalnej formy realizmu - to „realizm modalny” Davida Lewisa ${ }^{7}$, zgodnie z którym wszystkie światy możliwe istnieją na tej samej zasadzie co świat rzeczywisty - z tym że „świat rzeczywisty” należy rozumieć nie jako coś absolutnego, ale jako pojęcie indeksalne, wskazujące świat, jakim on jest z punktu widzenia, w którym się znajdujemy. Jak zobaczymy, każda z tych trzech koncepcji może mieć znaczenie dla krytyki genetycznej, która w swoim poszukiwaniu produktywnych modeli nie musi się sytuować między nimi.

Pojęcie świata możliwego pozwoliło poczynić znaczące postępy w odpowiedziach na wiele pytań, wzbudziło ożywione zainteresowanie wśród filozofów, ale też przedstawicieli wielu innych dyscyplin ${ }^{8}$. Szybko zdano sobie sprawę z tego, że zastosowane pojęcie, także w filozofii, było często dalekie od tego, jakim posługiwali się logicy, i że w znacznej mierze opierało się ono na analogii, a nie na ścisłym użyciu (co nie jest wadą, pod warunkiem że wszyscy są tego świadomi i że analogia więcej spraw wyjaśnia niż przesłania). Podkreślmy, że chodzi przede wszystkim o sposób stawiania problemów.

Zupełnie naturalne wydaje mi się zbliżenie teorii światów możliwych do teorii fikcji. Można dokonać próby powiązania statusu fikcji ze statusem wypowiedzi modalnych lub statusem wspomnianych wcześniej wypowiedzi kontrfaktycznych. Tradycyjna logika nie radzi sobie z wypowiedziami dzieł fikcyjnych: nie potrafi przypisać im wartości prawdy lub też uznaje, że są całkowicie fałszywe ${ }^{9}$. Sugerowaliśmy, że fikcja opiera się na „inwersji modalności”, to znaczy, że tryb oznajmujący, którego często używa, zastąpiłby tryb warunkowy ${ }^{10}$. Czy sytuacje kontrfaktyczne nie ustanawiają powieści zaludnionych fikcyjnymi tworami (kangury bez ogona, Joyce bez okularów, ja, które nie byłoby odwrócone i które by nie widziało)?

\footnotetext{
${ }^{5}$ Mówi on o „przemijaniu możliwego”. Nelson Goodman, Faits, fictions et prédictions (Paris: Éditions de Minuit, 1985), 74. Pojęcie możliwego zostaje zastąpione pojęciem dyspozycji: zamiast powiedzieć „jest możliwe, że ten rozdział zostanie rozwinięty” Goodman powiedziałby „ten rozdział jest rozwijalny”, co pozwala uniknąć odwołania do fikcyjnego stanu rzeczy i zastąpić go opisem rzeczywistości. Na pierwszy rzut oka takie postępowanie nie wydaje się zbyt obiecujące dla krytyki genetycznej. Nie starając się być większym nominalistą od króla, możemy naiwnie zauważyć, że język fikcji, aż do deformacji, jakich dokonał Joyce, nie był uznawany za odkształcalny. Tym, czego szuka genetyk, jest możliwość pomyślenia o powstaniu nowego predykatu dyspozycyjnego.

${ }^{6}$ Zob. zwłaszcza: Nelson Goodman, Of Mind and Other Matters (Cambridge: Harvard University Press, 1984), 125.

${ }^{7}$ David Lewis, Counterfactuals (Cambridge: Harvard University Press, 1973).

${ }^{8}$ Possible Worlds in Humanities, Arts and Sciences, Proceedings of Nobel Symposium 65, red. Sture Allén (Berlin, New York: Walter de Gruyter, 1989).

${ }^{9}$ A jednak, jak zauważa Umberto Eco (The Limits of Interpretation [Bloomington: Indiana University Press, 1994, 64), bez wahania oblejemy na egzaminie studenta literaturoznawstwa, który nie potrafi orzec, czy zdanie „Desdemona jest wierna” jest prawdziwe i czy zdanie „Emma Bovary jest wierna” jest fałszywe.

${ }^{10}$ Zob. Catherine Kerbrat-Orecchioni w jej prekursorskim tekście „Le texte littéraire: non-référence, autoréférence ou référence fictionnelle", Texte (1982): 38.
} 
Takie podejście otwiera wiele różnych dróg, ale wiąże się także z wieloma trudnościami, które zostały systematycznie opisane przez Ruth Ronen ${ }^{11}$. Debaty nad nim są ciągle ożywione ${ }^{12}$, ale ogólnie uznaje się, że jest ono uzasadnione płodnością sądów teoretycznych, które umożliwia $^{13}$. Nie będziemy w tym miejscu omawiać zbioru tych prac ani wątpliwości, jakie one podejmują. Interesują nas one o tyle, o ile mają znaczenie dla teorii genetycznej.

\section{Światy porównywane i światy ustanowione}

Zanim przejdziemy do rzeczy, konieczne jest wskazanie dwóch wstępnych warunków metodologicznych. Po pierwsze, pojęcie świata możliwego jest przywoływane w różnych kontekstach, ale - jak zauważa Umberto Eco - jest użyteczne wyłącznie wtedy, kiedy chcemy zestawić i „porównać wiele różnych stanów rzeczy", świat rzeczywisty i świat możliwy lub światy możliwe między sobą ${ }^{14}$. Po drugie, nie należy zapominać o tym, że światy możliwe są konstruktami. Nie są to światy obserwowalne, jak odległe planety badane w rzeczywistym świecie za pomocą potężnych urządzeń optycznych, są to światy ustanowione ${ }^{15}$.

Pierwsza z tych uwag powinna zostać potraktowana jako zachęta dla krytyki genetycznej. Dobrze wiemy, że podstawą metody genetycznej jest porównanie: porównanie zbiorów przed-tekstowych i ich różnic werbalnych, ale też, do czego wrócimy, porównanie znaczeń wytworzonych w różnych wersjach ${ }^{16}$ i porównanie światów opisanych przez te formy werbalne i przedstawione za pomocą tych znaczeń.

Druga podejmuje problemy o wiele trudniejsze, ale mogłaby zostać również uznana za korzystną w podejściu genetycznym. Z chęcią powtórzymy za czołowymi teoretykami fikcji, że

\footnotetext{
${ }^{11}$ Ruth Ronen, Possible Worlds in Literary Theory (Cambridge: Cambridge University Press, 1994), passim.

${ }^{12} \mathrm{~W}$ latach 2005-2006 poświęcono temu seminarium „La théorie des mondes possibles: un outil pour l'analyse littéraire?”, którym kierowała Françoise Lavocat. Podsumowania są dostępne online: https://tinyurl.com/ y59gaaeo (dostęp: 30.05.2020).

${ }^{13} \mathrm{~W}$ obszernym zbiorze bibliograficznym w języku francuskim dysponujemy tekstami: Umberto Eco, Lector in Fabula ou la Coopération interprétative dans les textes narratifs (Paris: Grasset, 1985) [w języku polskim Umberto Eco, Lector in fabula. Współdziałanie w interpretacji tekstów narracyjnych, tłum. Piotr Salwa (Warszawa: PIW, 1979) - wszystkie odwołania i cytaty podaję za tym wydaniem - przyp. tłum.] i Thomas Pavel, Univers de la fiction (Paris: Éditions du Seuil, 1988). Warto również sięgnąć do pracy Marie-Laure Ryan, Possible Worlds, Artificial Intelligence and Narrative Theory (Bloomington: Indiana University Press, 1991), a także Lubomira Doležela, Heterocosmica. Fiction and Possible Worlds (Baltimore: The Johns Hopkins University Press, 1998). Wprowadzenie Françoise Lavocat opublikowane jest również online: L'oeuvre littéraire est-elle un monde possible?, https://tinyurl.com/y4ecqdkv (dostęp: 30.05.2020)

${ }^{14}$ Eco, Lector in Fabula, 56.

${ }^{15}$ „Świat możliwy nie jest odległą krainą, którą napotykamy po drodze, czy którą oglądamy za pomocą teleskopu. Ogólnie rzecz biorąc, świat możliwy, odmienny od naszego, jest bardzo oddalony: nawet jeśli będziemy podróżować szybciej od światła, to do niego nie dotrzemy. Świat możliwy jest dany pod warunkami opisowymi, jakie z nim wiążemy. [...] «Światy możliwe» są ustanowione, nie odkrywa się ich za pomocą wielkich teleskopów”. Saul Kripke, La Logique des noms propres (Naming and Necessity) (Paris: Éditions de Minuit, 1982), 32.

${ }^{16}$ Doležel mówi w tym względzie o świecie intensjonalnym w opozycji do świata ekstensjonalnego - Lubomir Doležel, „Extensional and Intensional Narrative Worlds”, Poetics, nr 8 (1979), 193-211. W genetyce, podobnie jak w semantyce, ważne jest odróżnienie sensu (intensja, „tryb zapisu referencji”) i referencji (ekstensja), w tej sytuacji nie ma potrzeby posługiwania się pojęciem świata. Światy intensjonalne są bezpośrednio powiązane z formą ekspresji (z tym, co nazwiemy poniżej światami tekstowymi), nie cieszą się autonomią (nawet częściową), jaką posiadają światy ekstensjonalne.
} 
światy fikcyjne są przedmiotami skonstruowanymi: są one poczęte przez tekst dzieł, które udają, że je opisują, ale które również je ustanawiają (w opisie, którego dokonał Poe, nie istnieje jakiś uprzedni dom Usherów). $Z$ drugiej strony można by pomyśleć, że przedmioty krytyki genetycznej są przedmiotami obserwowanymi, a nie skonstruowanymi: genetyk obserwuje dokumenty, wersje tekstowe, które ma przed oczami (lub które stara się zrekonstruować przez wnioskowanie, jeśli brakuje jakichś dokumentów). Natomiast historyk musi stale budować scenariusze kontrfaktyczne, aby zrozumieć, co rzeczywiście się wydarzyło ${ }^{17}$, genetyk (w pierwszej chwili) ma odkryć możliwości zaktualizowane na papierze.

Podobnie jak światy Leibniza w boskiej świadomości, tak i światy przed-tekstu współistnieją w rękopisach. Są one dostępne za pośrednictwem pracy filologicznej, która odgrywa rolę pośredniczącej Ateny. Można je odwiedzać, kontemplować, także za pomocą narzędzi optycznych (lupa badacza rękopisów). Jednak przeciwnie do światów Leibniza, które istnieją w całej wieczności, tam, gdzie Stwórca sam je odkrywa, ale ich nie tworzy, światy przed-tekstu są światami ustanowionymi. Rękopisy, bez względu na formę gramatyczną, jaką przybierają, mogą być analizowane jako przepisy ${ }^{18}$ : są one wytycznymi, które finalnie obierają za cel ostateczną konstrukcję tekstu. Należy doprecyzować, że ta konstrukcja dokonuje się przez ustanowienie serii pośrednich (sukcesywne przybliżenia ostatecznej formuły) etapów tekstowych, ale też przez stopniową konstrukcję świata, do którego będzie odsyłał ostateczny tekst, konstrukcję, która sama przybiera formę ustanowienia światów pośrednich (pozwala na opracowanie etapami takich elementów, jak postaci czy wystrój).

\section{Światy tekstowe i światy fikcyjne}

W ramach genezy mamy zatem do porównania dwa typy światów możliwych: światy tekstowe i światy fikcyjne ${ }^{19}$. W wypadku światów tekstowych chodzi o słowa, zdania, ich układ na kartce, formuły i techniki literackie: przed-tekst projektuje alternatywne wersje konfiguracji tekstowych. W ten sposób na czele pierwszego planu Pani Bovary (il. 1, ms. gg 9, Bibliothèque municipale de Rouen) zaprojektowane są dwie wersje dzieła, dwa wirtualne światy tekstowe zostają skonfrontowane, jeden wpisuje się w pierwszą linię głównego bloku pisma („Charles Bovary officier de santé 33 ans quand commence le livre veuf déjà d'une femme plus vieille que lui”), drugi w marginalny dodatek („Commencer par son entrée au collège”): albo powieść, która zaczyna się, kiedy Charles jest dorosły, albo powieść, która zaczyna się, kiedy jest młodzieńcem.

\footnotetext{
${ }^{17} Z$ ob. Paul Veyne, Comment on écrit l'histoire, suivi de Foucault révolutionne l'histoire (Paris: Éditions du Seuil, 1979), 78-79. W uogólnieniu: „In the concept of an action is [...] implicit a comparison or contrast between a state of affairs resulting from the action and another state which would otherwise, i.e. had it not been for the performance of the action, have obtained [...] That which "would have otherwise have obtained» never comes true (occurs). It is 'contrary to fact'”. Georg Henrik von Wright, Causality and Determinism (New York: Columbia University Press, 1974), 41.

${ }^{18}$ Zob. Daniel Ferrer, „Quelques remarques sur le couple énonciation-genèse”, Texte, nr 27/28 (2000), „L'énonciation/la pensée dans le texte”, http://french.chass.utoronto.ca/unsorted/litera/Revue Texte/ferrer. pdf, 8-23.

${ }^{19} \mathrm{~W}$ niniejszym artykule większość przykładów jest zapożyczona z gatunku powieści, ale światy fikcyjne nie są zastrzeżone dla tego, co ogólnie określamy jako fikcję. Wbrew temu, co można by sądzić, odgrywają one szczególnie ważną rolę w genezie poezji.
} 


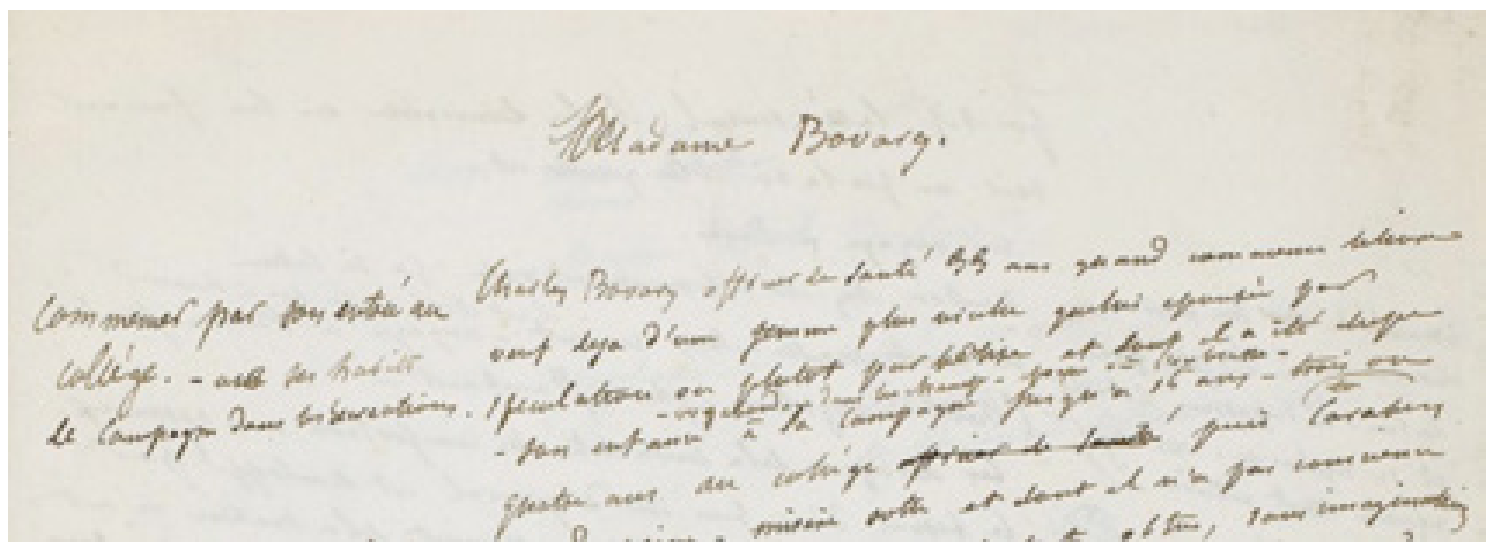

Ilustracja 2. Fragment rękopisu Madame Bovary. Ze zbiorów Bibliothèque municipale de Rouen. Fot. Thierry Ascencio-Parvy

Pierwsze rozwiązanie nie implikuje innego świata fikcyjnego: młodość Charles’a mogła być opowiedziana za pomocą cofnięcia w czasie lub też mogła pozostać w cieniu i nie zostać rozwinięta (zob. poniżej podrozdział „Niekompletność?”), ale nie ma żadnego szczególnego powodu, aby myśleć, że byłaby ona substancjalnie odmienna. Stawką w grze są dwa światy tekstowe. Aby rzecz dobitnie wyjaśnić, posłużymy się innym przykładem, który wiąże się ściśle ze sformułowaniem: alternatywa między światem tekstowym, którego ostatnie zdanie zawierałoby słowa „un gigantesque perroquet” (pierwszy brulion Prostoty serca, BnF, ms., nafr, 23663-349 v), i światem, który zawierałby (podobnie jak wersje następne) „un perroquet gigantesque”.

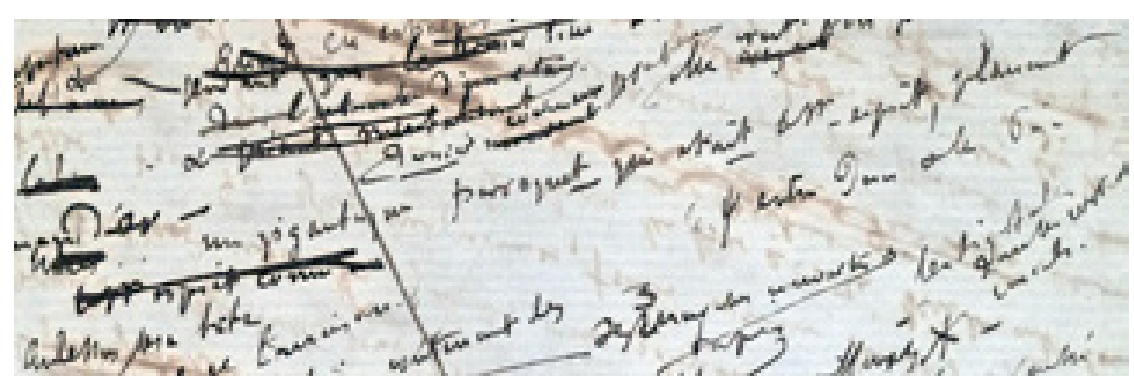

Ilustracja 3. Fragment rękopisu Madame Bovary. Ze zbiorów Bibliothèque municipale de Rouen. Fot. Thierry Ascencio-Parvy

Czy istnieje tu jakakolwiek potrzeba przywołania pojęcia świata możliwego? To pojęcie przypomina przede wszystkim, że zestawiając słowa wpisane w rękopis, zestawiamy w rzeczywistości dzieła wirtualne, ustanowione przez słowa. Pozwola ono także odwołać się do pojęcia dostępności. Wreszcie, co starałem się pokazać w innym miejscu ${ }^{20}$, to właśnie pojęcie tożsamości w światach możliwych pozwala rozwiązać, kładąc nacisk na ideę „bezwzględnego desygnatora", kwestię tożsamości dzieła w jego wersjach (jak można powiedzieć, że opowiadanie, które zaczyna się w trzydziestym trzecim roku życia Charles'a Bovary, jest wersją słynnego tekstu zaczynającego się od słów: „Nous étions à l'Étude, quand le Proviseur entra, suivi d'un nouveau habillé en bourgeois...”?) i tym samym ustalić definicję przed-tekstu.

${ }^{20}$ Ferrer, „La toque de Clementis...”, 98-100. 
Zaleta konfrontacji światów fikcyjnych w ramach genezy jest łatwiejsza do zauważenia. Trzeba jednak wpierw ustalić, co rozumiemy przez pojęcie „świat fikcyjny”. Niektórzy teoretycy eksplicytnie odebrali dziełu fikcyjnemu zdolność referencji, usiłując je zredukować do fraz, które je tworzą, czy też do gry powtórzeń intertekstualnych. Jednak znacznie szerszą grupę tworzą krytycy, którzy - nie formułując takiego zaprzeczenia - zignorowali w praktyce problemy referencji. Krytyka genetyczna włożyła mnóstwo energii w badania genezy form i znaczeń, ale z mniejszą uwagą przyglądała się genezie światów fikcyjnych. Bez wątpienia w różnych okresach. W latach rozwoju dyscypliny referencja stanowiła martwy punkt ${ }^{21} \mathrm{czy}$ nawet tabu w badaniach literackich w ogóle 22 , skądinąd szczególnie ważne było oddzielenie się od tradycyjnej wizji genezy jako mimetycznego procesu transpozycji rzeczywistości na dzieło. Jednak genetyka tekstów nie może sobie pozwolić na zgrabne obejście problemu, jak dzieje się to w innych obszarach krytyki, ponieważ referencja odgrywa ważną rolę w procesie wytwarzania tekstów.

Z punktu widzenia lektury jest rzeczą jasną, że to tekst dzieła generuje tryb fikcyjny, opowiadanie, które wytwarza diegezę (zob. podrozdział „Apendyks terminologiczny”), ale z punktu widzenia pisania, rzeczywistego generowania dzieła, rzeczy są o wiele bardziej złożone ${ }^{23}$. Prawdą jest, że w niektórych wypadkach referencja jawi się jako pewien rodzaj produktu ubocznego. W pierwszym brulionie epizodu Syreny w Ulissesie Joyce używa słów „crushed strawberry”, aby opisać suknię wicekrólowej. Począwszy od drugiego brulionu, kolor ten zostaje zastąpiony innym: „eau de Nil”. Zmiana zdaje się uzasadniona kwestią rytmu, ale też i sensu: konotacje obydwu terminów są różne, a nazwa „eau de Nil” nasyca bardzo ważny paradygmat akwatyczny, który zostaje wzmocniony w kolejnych wersjach. A jednak skutkiem są dwa różne światy fikcyjne: jeden, w którym wicekrólowa jest ubrana na czerwono, i drugi, w którym jest ubrana na zielono.

Kolejny przykład jest jeszcze bardziej znaczący, a dotyczy nonsensownego wiersza The Walrus and the Carpenter, który rozmyślnie obiera za cel proces referencji. Lewis Caroll ujawnił fakt, że zaproponował swojemu ilustratorowi Tennielowi, aby ułatwić mu zadanie, zastąpienie postaci cieśli („Carpenter”) „baronetem” czy nawet motylem („butterfly”) lub

\footnotetext{
${ }^{21}$ Przykładem emblematycznym jest Barthes. Ciekawe jest to, że wobec rękopisu obraz światów zwielokrotnionych w sposób naturalny nasuwał mu się pod pióro, ale tworząc inwentarz tych światów, unika on całkowicie światów reprezentowanych (czego nie da się zredukować do „sensu powiązanego”): „Mam przed sobą kartkę rękopisu; [...] uruchamia się coś, co nazywamy lekturą. Czym jest ta lektura, dokąd zmierzam, w którym miejscu mam się zatrzymać? Z całą pewnością wiem, w jakiej przestrzeni porusza się moje oko, ale ku czemu zmierza? Do jakiej innej przestrzeni się dostosowuje? Czy wychodzi poza kartkę? (ale poza kartką jest stół). Jakie obszary zajmuje każda lektura? W jaki sposób jest skonstruowana kosmogonia, której domaga się to proste spojrzenie? Jak samotny kosmonauta przemierzam te światy, w żadnym z nich się nie zatrzymując: biel papieru, forma znaków, postać słów, reguły języka, przymusy komunikatu, obfitość sensów powiązanych”. Roland Barthes, „Variations sur l'écriture «Infini»”, w Roland Barthes, Oeuvres complètes, t. 3, 1564. Cyt. za: Jean-Louis Lebrave, „La genèse de «La Chambre claire»", Genesis, nr 19 (2002), 79.

${ }^{22} Z$ ob. Kerbrat-Orecchioni, „Le texte littéraire: non-référence, auto-référence ou référence fictionnelle”.

${ }^{23}$ Doležel dokonuje absolutnego rozróżnienia między I-tekstami (world imaging texts), których funkcją jest reprezentowanie świata rzeczywistego, a ten w sposób konieczny je uprzedza, oraz C-tekstami (world constructing texts), których funkcją jest budowanie światów, jakie wcześniej nie istniały. Tym samym przeciwstawia się radykalnym konstruktywistom, takim jak Goodman, dla których wszystkie światy są skonstruowane przy użyciu słów lub innych symboli. Dla Doležela obraz świata opisany przez I-teksty jest ciągle przekształcany w procesie walidacji i odrzucenia, podczas gdy świat fikcyjny jest ustalony „once its creator has fixed the constructing text” (Doležel, Heterocosmica. Fiction and Possible Worlds, 26). Nie jest pewne, czy światy fikcyjne, których pisanie zostało ukończone, są tak naprawdę ustalone, jak mówi Doležel, ale w każdym razie w ramach genezy nic nie jest ustalone i jednocześnie wszystko jest ruchome.
} 
jakąkolwiek inną istotą, której nazwa byłaby prozodycznie równoważna. Dobitnie świadczy to o tym, że referencja jest następstwem dodatkowym, prostym efektem doboru słów, ale jednocześnie należy podkreślić znaczenie i możliwość wpływania na tekst ilustracji, która ustali jego znaczenie ${ }^{24}$.

W innych przypadkach, bez wątpienia licznych, referencja stoi na czele i to ona służy za podstawę genezy. Kiedy Flaubert wpisuje do scenariusza inicjalnego zbioru Prostoty serca „vision mystique. Son perroquet est le St Esprit", to te słowa nie dotyczą bezpośrednio ostatecznego sformułowania (nie pojawiają się w ostatecznym tekście, ani nawet w żadnym z brulionów), ale sytuacji (w tym wypadku myślowej), do której odeśle tekst, do stanu świata fikcyjnego, który opisze nowela. Nawet dla takiego pisarza jak Flaubert formuła tekstowa jest najczęściej drugoplanowa (ale z pewnością nie wtórna): „Le mot ne manque jamais quand on possède l'idée", jak pisał do George Sand ${ }^{25}$. Odtąd genetyk może porównywać świat ustanowiony przez scenariusz inicjalny, w którym Felicyta umiera w szpitalu, ze światem ułożonym według takiego scenariusza, w którym Felicyta umiera (w swoim pokoju) w Boże Ciało.

Zmiany tekstu, które mają wytworzyć efekty sensu czy efekty brzmieniowe (dobór rymów), mają zwykle wpływ na świat fikcyjny zaprojektowany przez tekst ${ }^{26}$. Często zdarza się, że manipuluje się światem fikcyjnym po to, aby ułatwić narrację. W ten sposób Zola, planując początek Marzenia, zamierza przenieść swoją bohaterkę ściganą przez śnieg, aby móc dogodniej opisać rzeźby portalu, pod którym się schroniła: „Et alors, à mesure que la neige tombe et que le jour se lève, se servir de l'enfant qui change deplace devant l'envahissement de la neige, pour décrire la porte"27.

Logika właściwa światu fikcyjnemu („Si Félicien répare le vitrail, il faut un échafaudage”28) przeciwnie - będzie miała wpływ na tekst i powiązanie znaczenia w takim stopniu, w którym często trudno jest określić, jak oddziałują na siebie poszczególne poziomy, i trudno jest (choć to konieczne) oddzielić od siebie dwa poziomy ${ }^{29}$.

\section{Niekompletność?}

Poruszając zagadnienie światów fikcyjnych, trzeba koniecznie odnieść się do problemu, który poruszył teoretyków fikcji - chodzi o integralność światów. Światy możliwe w logice są

\footnotetext{
${ }^{24}$ Zob. artykuł Christine Collière, „Illustrating the Sylvie and Bruno Books: the Collaboration of Lewis Carroll and Harry Furniss", Recto Verso, nr 3, www.revuerectoverso.com/spip.php?article90 (dostęp: 30.05.2020).

${ }^{25}$ List z 10 marca 1876 roku.

${ }^{26}$ Zob. wyżej podstawowy przykład z Syren. Zob. także: Ferrer, „Le matériel et le virtuel: du paradigme indiciaire à la logique des mondes possibles", 26-27, przykład zaczerpnięty z Dostojewskiego pokazuje, w jaki sposób zmiana trybu narracji prowadzi pośrednio do przekształcenia przestrzeni świata fikcyjnego.

${ }^{27}$ Plan Marzenia, karta 4. Z łatwością odnajdziemy inne przykłady, w wielu wypadkach pojawia się potrzeba nowej perspektywy narracyjnej, wprowadzenie dodatkowej postaci, która może ukierunkować fokalizację.

${ }^{28}$ Zola, plan Marzenia, karta 71.

${ }^{29}$ Choć znaczeń nigdy nie da się przekształcić całkowicie, to jednak wszystko, co wchodzi w skład odniesienia, można zwykle sprawnie sparafrazować, bez pozostałości i dwuznaczności (na przykład tę samą trasę można precyzyjnie określić za pomocą różnych wzorów). Ale w dziedzinie fikcji, gdzie tekst wytwarzający sens jest źródłem referencji, nie może istnieć dokładna parafraza, nawet na tym poziomie.
} 
światami wirtualnie kompletnymi. Światy fikcji zdają się niekompletne, zaludnione niekompletnymi jednostkami, tzn. nieposiadającymi, co jest konieczne w wypadku przedmiotów rzeczywistych, wartości dla każdej z możliwych właściwości: nie wiemy i nigdy się nie dowiemy, ile dzieci miała Lady Macbeth czy też ile okien ma dom Usherów. Można się upierać przy tym, że ta niekompletność nie jest ontologiczna, ale epistemiczna ${ }^{30}$ : nie znamy tych liczb, ale one istnieją ${ }^{31}$ W światach fikcyjnych, do jakich odsyłają sztuka Szekspira i opowiadanie Poego, właściwości te należałoby ustalić. W każdym razie, w ramach genezy, nieokreśloność właściwości jawi się w innym świetle.

To, co nie jest określone w tekście, może być określone w brulionie. Nie dysponujemy rękopisami dzieł, które cytujemy, ale możemy się odnieść po raz kolejny do rękopisów Pani Bovary. Bruliony mówią o życiu seksualnym Emmy znacznie więcej niż wersja ostateczna. Powieść, $\mathrm{z}$ racji wyborów dokonanych przez Flauberta lub z powodu przymusów społecznych, jakie ucieleśnia prokurator Pinard, pomija te drażliwe detale. Jednak nawet z pomocą najbardziej jednoznacznych rękopisów nigdy się nie dowiemy, ile orgazmów miała pani Bovary, ponieważ świat zaprojektowany przez powieść nie jest światem zaprojektowanym przez każdą z wersji uprzednich, a ta liczba niekoniecznie jest taka sama w każdym ze światów ${ }^{32}$. Niemniej jednak jest to liczba poprawna w każdym ze światów, liczba określona, która jest czasami wyjaśniona, a czasami nie.

Jeszcze bardziej pouczające jest spojrzenie na większą niepełność pojawiąjącą się w wielu wersjach przed-tekstowych. Przyjrzyjmy się wpierw przypadkowi światów tekstowych. Kiedy Flaubert w trzecim scenariuszu Prostoty serca pisze to poszatkowane i pełne luk zdanie: „et quand elle exhala son dernier souffle... quand (une phrase très longue) cette vie terrestre s'éteignit... elle crut voir le Perroquet planant au-dessus de sa tête", to jest jasne, że nie planuje niepełnego, dziurawego zdania, ale długi i harmonijny okres, który ma domknąć jego opowieść. To, co jest prawdziwe w planie słów, jest takie, a nawet jest czymś więcej, w planie świata przedstawionego. Początkowy scenariusz odnotowuje jedynie „elle meurt saintement”, opis śmierci Felicyty ewidentnie jawi się jako niepełny w stosunku do tego, jaki znajdzie się w tekście ostatecznym, ale jest on wypełniony szczegółami, które wyłonią się później (ewentualnie także i innymi szczegółami). Jest rzeczą jasną, że przedstawiony świat fikcyjny nie ma w sobie niczego niekompletnego, lakoniczne jest jedynie wyrażenie. Paradoksalnie możemy powiedzieć to samo o najbardziej rozwiniętej i rozwlekłej wersji.

\footnotetext{
${ }^{30}$ Jest to koncepcja broniona przez Marie-Laure Ryan. Doležel, Eco i Ronen nie są tego samego zdania, ale ich argumenty nie wydają się zbyt przekonujące. Ten sposób prezentacji rzeczy przypomina Kripke: „Świat możliwy jest dany przez warunki opisowe, które z nim kojarzymy. [...] Oczywiście nie wyobrażamy sobie wszystkiego, co jest prawdą lub fałszem, a jedynie rzeczy, które mają związek z naszą hipotezą; w teorii jednak, aby podać pełny opis świata, należy decydować o wszystkim. Nie możemy sobie tego wyobrazić, jedynie częściowo; 'świat możliwy' to właśnie to”. Kripke, La Logique des noms propres (Naming and Necessity), 32. A także: „Oczywiście, gdy określamy sytuację kontrafaktyczną, nie opisujemy całego świata możliwego, a jedynie tę część, która nas interesuje" (Kripke, 37, n. 16). Jak widzieliśmy, sytuacje kontrafaktyczne można porównać do mikropowieści.

${ }^{31} \mathrm{Aby}$ się o tym przekonać, wystarczy przyjrzeć się problemowi, który dotyczy fikcji; chodzi o sytuację, kiedy pisarz udaje, że sprowadza niekompletność reprezentacji tekstowej do reprezentowanego świata (Sterne, Pirandello, Stoppard...). Zob. przykładową analizę genezy tego procesu u Joyce'a: Daniel Ferrer, „Peut-on parler de métalepse génétique?”, w Métalepses: Entorses au pacte de représentation, red. John Pier i JeanMarie Schaeffer (Paris: Éditions de l'École des Hautes Études en Sciences sociales, 2005), http://www.item.ens. fr/index.php?id=13987 (dostęp: 30.05.2020).

${ }^{32}$ Zob. emblematyczny przypadek Gerwazyny, która nie ma tej samej liczby dzieci w światach fikcyjnych $W$ matni i w Bestii ludzkiej.
} 
Jest jednak pewne zastrzeżenie. Mamy zwyczaj zapełniać luki w wiedzy o świecie fikcyjnym, posługując się w dużej mierze naszą wiedzą ekstrafikcyjną. Flaubert nie podaje w Prostocie serca liczby nóg swoich postaci ani geograficznego położenia Rouen, ale bierzemy za pewnik to, że Felicyta ma dwie nogi i że miasto, w którym mieszka, jest położone na zachód od Paryża $^{33}$. Na podstawie tego uzasadnionego wnioskowania mamy skłonność do uzupełniania braków w eliptycznych wersjach rękopisów na zasadzie zapożyczeń z wersji ostatecznej. Jest to udogodnienie dla naszej osłabionej wyobraźni, ale trzeba mieć świadomość, że nie jest to uzasadnione na podstawie jakichś zasad prawnych. W materii genezy nie możemy sądzić, że wszystkie rzeczy w jakiś sposób sobie odpowiadają.

\section{Możliwe}

Jeśli uznamy, że światy tekstowe i światy fikcyjne nakładają się na siebie i są ze sobą złączone, czasami nawet nierozerwalnie ${ }^{34}$, w przed-tekście, to trzeba doprecyzować ich status. O partykularnym charakterze badań genetycznych decyduje złożoność stausu. Jak widzieliśmy, te światy są zarazem rzeczywiste i wirtualne. Bezsprzecznie są one obecne w dokumentach, ich obecności dowodzi fakt, że czytelnik może się z nimi zapoznać, przeczytać w tym celu brulion, jakby czytało się tekst ostateczny, wejść w fikcyjną przestrzeń, zaczynając od scenariusza tak samo jak od ukończonego tekstu. Dla samego pisarza światy, które tworzy, zaczynają istnieć w chwili ich zapisywania. Jak mówi Jean Bellemin-Noël, to, co jest zapisane, nigdy nie jest odgórnie i według miejsca przeznaczenia pojmowane jako odpad, nawet „wstępny szkic”, który ulegnie zmianie, może pozostać nienaruszony. Zazwyczaj dopiero po fakcie rozpoznaje się błędne ukierunkowanie, ślepy zaułek, usterkę. Coś początkowo nieudane, choćby przez jedną chwilę było prowizorycznie udane ${ }^{35}$. Coś prowizorycznie ostateczne zostanie jednak definitywnie oznaczone pieczęcią prowizoryczności, w zawieszeniu, do zakończenia „mając szansę” na pozytywne domknięcie. Jego istnienie jest projekcyjne, jawnie lub domyślnie zmodalizowane. Nierzadko zdarza się, że modalizacja wyraża się w sposób bezpośredni. Tak się dzieje w nocie Stendhala na marginesie Luciena Leuwena: „Faut-il placer ce deuxième entretien avant le second duel? Ce serait plus narratif". Czasami to, co wydaje się domknięte, zostaje natychmiast zawieszone: „Il fera croire à Leuwen qu'elle est accouchée en secret. Du Poirier ne dit pas cela aux vicomtes mais il le pense, et moi auteur je me dis: Est-ce bon?" ${ }^{36}$. W szkicach i planach Zoli, które często ukazują to, co jest ukryte gdzie indziej, niejednokrotnie pojawiają się formy warunkowe, odnoszące się czasami do światów fikcyjnych, a czasami do światów tekstowych:

\footnotetext{
${ }^{33}$ Marie-Laure Ryan nazywa to zasadą „minimal departure”. O ile nie określono inaczej i jeśli nie ma obszerniejszego wyjaśnienia, przypuszczamy, że świat fikcyjny jest tożsamy w każdym szczególe z tym, co uważamy za świat rzeczywisty.

${ }^{34} \mathrm{O}$ ile każde zdanie przed-tekstu może być odczytane jako odnoszące się do pozycji wypowiedzi (w planie Marzenia wypowiedź „la neige tombe” odpowiada „Ja [Zola] decyduję (lub wyobrażam sobie), że na początku powieści będzie padał śnieg"), rozróżnienie świat tekstowy - świat fikcyjny mogłoby być sprowadzone do rozróżnienia de re - de dicto, którego dwuznaczności, w tym szczególnym kontekście, nie dałoby się podnieść.

${ }^{35}$ Jean Bellemin-Noël, „Reproduire le manuscrit, présenter les brouillons, établir un avant-texte”, Littérature, nr 28 (1977): 7.

${ }^{36}$ Stendhal, CEuvres romanesques completes, red. Yves Ansel, Philippe Berthier i Xavier Bourdenet (Paris: Gallimard, 2007), 923.
} 


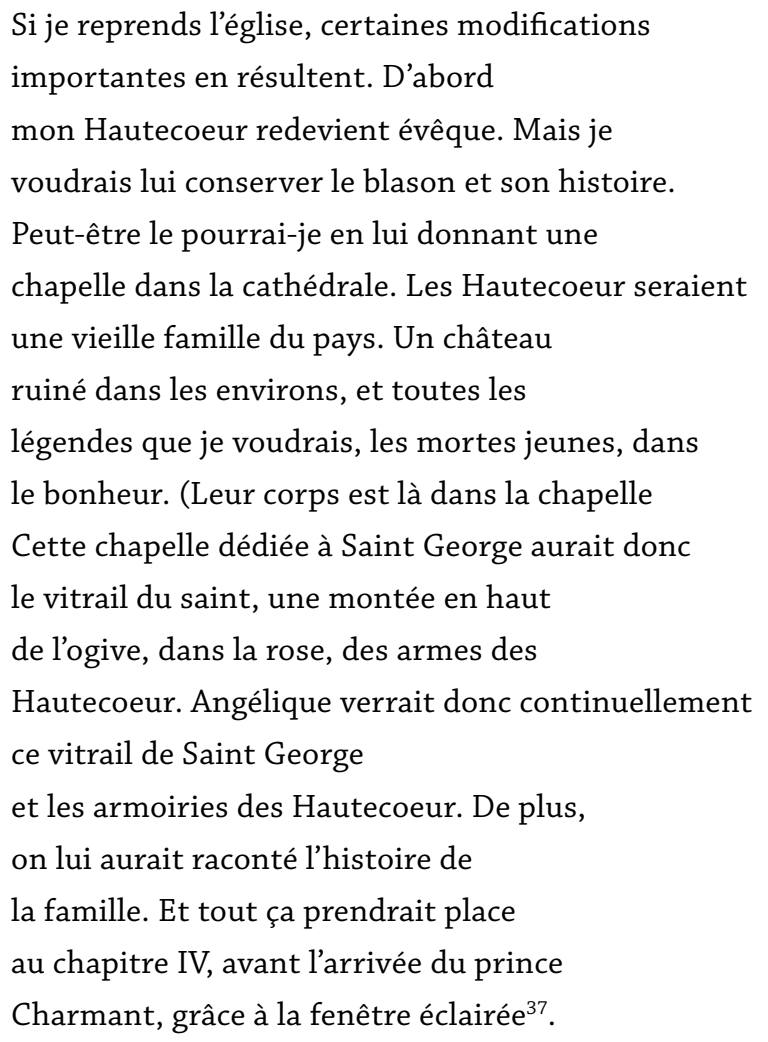

W większości rękopisów zakłada się jadnak modalizację. Jeśli fikcja opiera się na enallage modalności (tryb oznajmujący na tryb warunkowy), trzeba uznać, że przed-teksty fikcji składają się z wielu enallage modalności rozluźnionych na wiele sposobów (tryb oznajmujący twierdzący, podany zarazem w trybie warunkowym zaznaczającym projektowane zawieszenie i imperatywie przyszłej realizacji, zapowiadającym narracyjne oznajmienie podane w trybie warunkowym zaznaczającym fikcyjne zawieszenie...).

Kiedy Flaubert pisze „une attaque à l'hôpital/ elle meurt saintement”, wskazuje coś na kształt: „elle pourrait mourir saintement d'une attaque à l'hôpital” albo: „il faudrait qu'elle meure saintement...”. Tym samym, kiedy pisze słowa: „un gigantesque perroquet”, nie znaczy to, że w chwili pisania tych słów wierzy, że słowa „gigantesque perroquet” będą figurować w tej postaci w ostatecznym dziele. Daje się tu wyraźnie wyczuć, że poszukuje on rytmu opartego na anapeście, który trzeba udoskonalić. Metodą prób i błędów pisarze układają konstrukcję. Chodzi oczywiście o zmodyfikowany przepis. To zdanie z Zoli mówi o quasi-uniwersalnym użyciu w przed-tekście: „Pourtant, cela est à régler, lorsque j’aurai tous les éléments”38.

Przed-tekstowe światy są więc światami możliwymi. Są możliwe, ale w relacji do czego? Jaki jest punkt zakotwiczenia, jakie jest ich usytuowanie w odniesieniu do świata rzeczywistego? Wszystko zależy od przyjętej perspektywy. Z retrospektywnego punktu widzenia świat rzeczywisty jest dziełem dokonanym, takim, w jakie zamienia je wieczność. Światy możliwe, do-

\footnotetext{
${ }^{37}$ Plan Marzenia, karty 52-53, transkrypcja uproszczona. Zob. bardzo pomocną stronę, którą zespół „Zola” z ITEM i BnF poświęcił Marzeniu: https://gallica.bnf.fr/dossiers/html/dossiers/Zola/ (dostęp: 30.05.2020).

${ }^{38}$ Szkic Bestii ludzkiej, karta 593.
} 
stępne ze świata rzeczywistego, są to światy, które genetycy układają w przed-tekście szczególnego dzieła. Zasady dostępności są wyraźnie określone za pomocą gestu podziału, który definiuje przed-tekst. Mogą więc one nieco się różnić w kilku różnych ujęciach krytycznych ${ }^{39}$.

Z punktu widzenia pisania w toku każdy z tymczasowo zaadaptowanych światów, który był, jak mówi Bellemin-Noël, „przestrzenią chwilową” w rozwoju zdania, reprezentuje na przemian świat rzeczywisty. Obecność, jak u „realistów modalnych”, jest kwestią punktu widzenia. Światy dostępne ze świata rzeczywistego są potencjalnościami, które otwierają się od tego właśnie punktu ${ }^{40}$. I jeszcze wypowiedź Zoli: „Ważne jest, aby wiedzieć, czy zamknę powieść w świecie dziewcząt. Albo czy będę miał obok inny świat. Ten następny świat może mi trochę pomóc w udramatyzowaniu akcji”"11.

Te logiczne wirtualności, które pojawiają się do ostatniej chwili, nawet u pisarza uznawanego za deterministę („nie chcę powiedzieć, że jest tylko jedno możliwe rozwiązanie każdej powieści; istnieje wiele logicznych rozwiązań, w zależności od tego, czy powieściopisarz dysponuje dokumentami, których pozostaje panem, dopóki ich nie użyje" ${ }^{22}$ ), są zawarte w obfitości wariantów, wersji, skreśleń, nierozwiązanych alternatyw. Oczywiście pojawiły się inne możliwości, których nie potwierdza żaden ślad, ale krytyka genetyczna musi opierać swoją pracę na potwierdzonych możliwościach.

\section{Konieczne?}

Po przywołaniu tego hipotetycznego „świata obok”, który mógłby posłużyć do udramatyzowania akcji Nany, Zola dodaje: „Myślę, że to zakończenie intrygi jest konieczne”. W jednej chwili i bez namysłu przeszedł od wirtualności do konieczności.

Nie jest łatwo określić, czym może być „konieczne” w ujęciu genetycznym. Nie należy go mylić z oczywistością artystyczną, która dominuje w ostatecznym dziele, usiłującym „odsunąć je od nieprzewidzianych okoliczności”, zamykając je w „niezbędnych pierścieniach pięknego stylu”43. Można by się posłużyć koncepcją Eco, dla którego w światach fikcyjnych (i w uogólnieniu w światach

\footnotetext{
${ }^{39}$ „Zdefiniowanie przed-tekstu jako przedmiotu skonstruowanego polega na dopuszczeniu wielości możliwych konstrukcji”. Louis Hay, „"Le texte n'existe pas». Réflexions sur la critique génétique”, Poétique, nr 62 (1985): 152. „Przed-tekst jest tworem w sposób konieczny wyspecjalizowanej lektury, która implikuje wykorzystanie metody analizy tekstowej w odniesieniu do ruchomych realiów genezy. W tym samym dossier genezy może więc być tyle przed-tekstów, ile obranych do interpretacji punktów widzenia”. Pierre-Marc de Biasi, „L'analyse des manuscrits et la genèse de l'œuvre”, w Encyclopaedia Universalis, vol. Symposium (Paris: Bordas, 1985), 466-476.

${ }^{40}$ Istnieje oczywiście pewne podobieństwo (a nawet pewna symetria) między tymi wirtualnościami i antycypacjami, które pojawiają się w umyśle czytelnika, w miarę jak postępuje jego lektura ukończonego dzieła, „drogi wnioskowania” bliskie Eco (Lector in Fabula, 179-188). Ale w przeciwieństwie do projekcji pisarza ujawnionych w rękopisach, oczekiwania czytelnika nie są nigdzie potwierdzone, same są przedmiotem wnioskowania ze strony krytyka. Czasem jednak potwierdzają się przewidywane przez pisarza oczekiwania czytelnika.

${ }^{41}$ Szkic Nany. Kiedy Zola mówi o „światach”, tu lub w cytacie umieszczonym w egzerdze niniejszego artykułu, to nie ma wątpliwości, że odwołuje się wpierw do środowiska społecznego (do sfer społeczno-zawodowych, w których rozwijają się te postaci), ale takie użycie (podobnie jak użycie słowa „sfera”) opiera się na jakimś obrazie, bardziej lub mniej zleksykalizowanym, światów równoległych i relatywnie zamkniętych.

${ }^{42}$ List z 26 listopada 1879 roku, cytowany przez Colette Becker w: „Cela «s'établira en écrivant» (Zola)”, w Émile Zola, La Fabrique des Rougon-Macquart. Édition des dossiers préparatoires, oprac. Colette Becker przy współpracy Véronique Lavielle, t. 3 (Paris: Honoré Champion, 2006), 210-212.

${ }^{43}$ Marcel Proust, À la recherche du temps perdu, III (Paris: Gallimard, coll. „Bibliothèque de la Pléiade”, 1954), 889.
} 
skonstruowanych kulturowo) konieczność jawi się w dwóch aspektach: pierwszy to konieczność „topiczno-zmysłowa” (określona już na początku przez wybór pola ważności), a drugi to konieczność strukturalna (która opiera się na funkcjonalnej „współzależności zależności”: Otello i Desdemona są nawzajem i w sposób konieczny określeni jako „mąż Desdemony” i „żona Otella” ${ }^{44}$. Konieczność strukturalna panuje w światach leibnizowskich. W przypadku, gdy Tarquin zostanie królem, musi być przestępcą i zostanie wygnany z Rzymu: może unikać zbrodni i wygnania, ale tylko wtedy, gdy wybierze przeznaczenie, zgodnie z którym nie wstąpi na tron. Dyspozycja układu światów pozwala Atenie wykazać, że każda lokalna zmiana obejmuje całość. $Z$ tej przewrotnej perspektywy genetyka mogłaby wykazać porównywalną współzależność.

Należy wyjść od pojęcia „wariantu powiązanego”, zdefiniowanego przez Almutha Grésillona jako:

każdy wariant, który znajduje się pod presją danych kontekstowych (intra- lub inter-wypowiedź) lub danych tekstowych. Ta presja, której różne aspekty wymagają jeszcze doprecyzowania, powoduje konieczność zastąpienia X. Innymi słowy, pod wpływem danej A element X zostaje wykluczony ${ }^{45}$.

Rozumie się samo przez się, że skreślenie „my” i zastąpienie go „ja” implikują fakt, że następny czasownik podaje się w pierwszej osobie liczby pojedynczej. Zmiana końcówki jest więc wariantem „powiązanym”. Jest również jasne, że „Salomon”, imię ojca Miny, bohaterki Różowego i zielonego, zostało zastąpione imieniem „Pierre” w związku z zamianą frazy „nous avons beau avoir des millions, nous ne serons jamais que la femme et la fille d'un marchand" na „J'aurais beau avoir des millions, disait Mina à sa mère, en Allemagne dans le pays de la noblesse de race je ne serais jamais qu'une juive c'est à dire un être souverainement envié et malgré cette envie presque toujours méprisé", to znaczy w związku ze zmianą statusu Miny, która staje się, co Stendhal odnotował w rękopisie, „nie-żydowska”" ${ }^{6}$. Trzeba jednak pójść nieco dalej i uogólnić pojęcie powiązania za sprawą jego modulacji ${ }^{47}$. Musimy stwierdzić, że żaden wariant nie jest naprawdę wolny oraz że każda modyfikacja musi koniecznie wpisywać się w jeden lub wiele systemów, które praktykują na niej sprzeczności wynikające z różnych porządków. Genetycy, którzy nie mają wsparcia Ateny w ich wyjaśnianiu, nie zawsze mogą wytłumaczyć te sprzeczności, zwłaszcza kiedy nie mają one w sobie pięknej prostoty praw gramatyki. W szachach łatwo jest ustalić zasady, które zezwalają na poruszanie się po polu lub tego zabraniają, dużo trudniej jest analizować relacje, które w danym układzie łączą fragment pola ze wszystkimi innymi i które ograniczają jego działanie. Relacje są dynamiczne, rozprowadzane z każdym ruchem i ewoluują zgodnie z zamiarami graczy. W badaniach genetycznych chodzi o to samo.

\footnotetext{
${ }^{44}$ Eco, Lector in fabula, rozdz. 8: Struktury światów. Ronen (Possible Worlds in Literary Theory, 54) podkreśla, w jakim stopniu ta koncepcja konieczności różni się od koncepcji logiki modalnej.

${ }^{45}$ Almuth Grésillon, „Les variantes de manuscrits: critères et degrés de pertinence”, w La Publication de manuscrits inédits, red. Louis Hay i Winfried Woesler (Berne: Peter Lang Verlag, 1979), 183. Dans « Linguistique et génétique des textes : un décalogue » (Le Français moderne, numéro spécial : "Tendances actuelles de la linguistique française », Paris, CILF, 2008), Almuth Grésillon et Jean-Louis Lebrave adoptent une définition plus restrictive : «La variante sera dite liée quand elle est due à des contraintes de langue (morphologiques, lexicales, syntaxiques ou de règles d'enchaînement textuel) ou si elle n'est que l'effet grammaticalement nécessaire d'une variante première. Les variantes non liées sont dites libres. » On comprend qu'une telle définition soit plus opératoire pour l'analyse linguistique, mais elle est sans doute moins productive d'un point de vue théorique. Dans son article de 1979, Almuth Grésillon refusait de considérer qu'une variante puisse être libre (p. 186).

${ }^{46}$ Karta 6 brulionu zatytułowana „Tamira Wangen”.

${ }^{47}$ Almuth Grésillon mówi o „mniejszym lub większym [...] ograniczeniu stref działania”. Grésillon, „Les variantes de manuscrits: critères et degrés de pertinence", 183.
} 
Jeśli w dramacie Szekspira bycie „mężem Desdemony” i „żoną Otella” są koniecznymi właściwościami Otella i Desdemony, to niekoniecznie było tak w rękopisach: póki Szekspir nie zdecydował, że jego „tematem” nie jest zazdrość, Otello mógł być kawalerem. Dwie formy konieczności są ściśle ze sobą powiązane: konieczność strukturalna obowiązuje tylko w zależności od wyboru tematów, są one jednak stale adaptowane i ponownie reinterpretowane. Ostatecznie nawet zgodność czasownika w pierwszej osobie liczby pojedynczej po „ja”, którą podaliśmy jako przykład wariantu powiązanego, przestaje dominować, jeśli pojawi się rozmyślnie agramatyczna konstrukcja lub jeśli lokucja jest przypisana normandzkiemu wieśniakowi.

Możemy też posłużyć się słynnym przykładem wiersza Liberté. Wiemy, że w trakcie pisania zostało dosłownie narzucone rozchwianie tematyczne, nagła mutacja, a raczej reinterpretacja pola ważności (,je me suis vite aperçu que le seul mot que j'avais en tête était le mot libertét8"), które powierzchownie przełożyło się na jeden wariant, ale też wstrząsnęło wszystkimi wewnętrznymi relacjami w wierszu. Pozwoliło to Louisowi Hay stwierdzić, że tekst jawi się, w świetle genezy, jako „możliwe konieczne” ${ }^{49}$.

\section{Dostępności}

Łatwo zrozumieć, że kluczowym problemem jest przejście z jednego świata do drugiego. Jak widzieliśmy, logika modalna określa relacje między światami zwane relacjami dostępności. Określają one, do którego świata można uzyskać dostęp z innego. Dostępność może być przechodnia lub nieprzechodnia (jeśli świat $A$ jest dostępny dla świata $B$, który sam jest dostępny dla świata $C$, A niekoniecznie jest dostępny dla $C$ ), symetryczna lub niesymetryczna (jeśli świat A jest dostępny dla świata B, B jest nie zawsze dostępny dla A), refleksyjna lub nierefleksyjna (dany świat niekoniecznie jest dostępny dla siebie samego).

Jak zdefiniować takie relacje w kontekście genezy? Byłoby pasjonujące (i być może utopijne) móc rygorystycznie określić, co sprawia, że można lub nie można przejść od stanu X do stanu $\mathrm{Y}$, co sprawia, że wariant jest możliwy lub niemożliwy w danej chwili, w danym punkcie przed-tekstu.

Gdyby udało się określić taką relację dostępności, to łatwo się domyślić, że połączyłaby ona asymetrie częściowe i krzyżowe. W kierunku wstecznym stan $\mathrm{X}$ jest bez trudu dostępny $\mathrm{z}$ następnego stanu Y, podczas gdy dostęp do stanu Y ze stanu X nie jest taki oczywisty. Henri Bergson posługuje się przykładem dzieła sztuki, aby nas ostrzec przed mirażami możliwego:

można sobie wyobrazić, że wszystko, co powstaje, mogło być dostrzeżone z wyprzedzeniem przez świadomy umysł, i że w ten sposób istniało w formie idei w jego realizacji; - absurdalna koncepcja w przypadku dzieła sztuki, ponieważ gdy tylko muzyk ma dokładną i pełną ideę symfonii, którą

\footnotetext{
${ }^{48}$ Paul Éluard, Poésie de circonstance, cytowane przez Louisa Haya w: La Littérature des écrivains. Questions de critique génétique (Paris: José Corti, 2002), 57.

${ }^{49} \mathrm{Hay}$, „«Le texte n'existe pas». Réflexions sur la critique génétique”, 158. Zob. także takie ujęcie: „Geneza tekstu oferuje krytyce [...] kryterium inteligibilności, wykazując, czym dzieło mogłoby być i czym jest. Tak oto sąd estetyczny może wymóc konieczność tekstu, poczynając od możliwych, na których eksperymentował". Hay, La Littérature des écrivains. Questions de critique génétique, 29.
} 
skomponuje, jego symfonia już jest ukończona. Ani w myśli artysty, ani tym bardziej w żadnej innej myśli porównywalnej z naszą, nawet jeśli byłaby bezosobowa, nawet jeśli byłaby po prostu wirtualna, symfonia nie opiera się na jakości możliwego, zanim się urzeczywistni ${ }^{50}$.

Aby przejrzyście objaśnić pojęcie dostępności asymetrycznej, często podajemy następujący przykład: we współczesnym świecie, w którym istnieje telefon, świat bez telefonu łatwo sobie wyobrazić, ale w świecie bez telefonu trudno sobie wyobrazić świat, w którym istniałby telefon ${ }^{51}$. Jednak, na co zwraca uwagę Eco ${ }^{52}$, ten przykład zapomina, lub udaje, że zapomina, że istniał Graham Bell, który w świecie bez telefonu wiedział, jak zaprojektować (i stworzyć) świat, w którym istnieje telefon. Symfonia, którą przywołuje Bergson, mówi o tym, co nie było możliwe, ale w mocnym tego słowa znaczeniu jest zapisane. W domenie twórczości artystycznej chodzi o wynalazek, a wynalazki to transgresje w porównaniu do konwencji (ogólnych lub innych), które przepisują otwarte możliwości. Wielcy innowatorzy są dość podobni do Grahama Bella. Wybraliśmy wcześniej z ufnością zdanie „każde dzieło ma jakiś początek” jako przykład relacji konieczności, ponieważ to zdanie wydaje się prawdziwe we wszystkich światach dostępnych ze świata rzeczywistego. Jednak Finnegans Wake, z racji swojej okrężnej formy, nie ma ani początku, ani końca. Tym samym przed Joyce'em możliwe były jedynie dzieła literackie napisane w języku naturalnym, co nie przeszkodziło w stworzeniu Finnegans Wake. Jednak odrzucenie istniejących przymusów leksykalnych nie oznaczało, że każde słowo stało się możliwe w dowolnym momencie. Wprowadzano stopniowo nowe reguły dostępności: na tym opiera się istota Joyce'owskiego work in progress.

Moglibyśmy pójść dalej i stwierdzić, że w dowolnym pisaniu (ponieważ symfonia, o której mówi Bergson, niekoniecznie jest rewolucyjna) każdy stan $Y$ reprezentuje transgresję, nawet najmniejszą, w stosunku do ram, które kierowały rozwojem poprzedniego stanu X: jest on zupełnie nie do pomyślenia bez tych ram, jest niedostępny z X.

Inaczej mówiąc, $X$ jest niedostępne $Z$, ponieważ oryginalny projekt $X$ jest delikatnie (lub radykalnie) zmodyfikowany przez zmianę, która prowadzi do $\mathrm{Y}, \mathrm{w}$ taki sposób, że oryginalna perspektywa jest nie do odzyskania: $\mathrm{z}$ tego powodu twórcy są $\mathrm{w}$ tak niewielkim stopniu godni zaufania, kiedy mówią o genezie swoich dzieł. Mówiąc z punktu widzenia ukończonego dzieła, projekt początkowy, archaiczny, starzejący się, jest dla nich niedostępny.

$\mathrm{Z}$ tych samych powodów dostępność genetyczna jest nieprzechodnia: ponieważ z X nie jest możliwy dostęp do światów Za, Zb, Zc..., które będą dostępne z Y, i jeszcze mniej do światów, które będą dostępne $\mathrm{z}$ jednego ze światów $Z$.

Taki układ powinien umożliwiać uwzględnienie wirtualności procesu tworzenia bez konieczności zaprzeczania jego wymiaru czasowego, jak to miało miejsce w systemie Leibniza. Za pośrednictwem metafory przestrzennej (dostępność między światami) możemy spróbować przeanalizować czasowność nielinearną, nieciągłą, „akcydentalną”, która jest właściwa genezie.

\footnotetext{
${ }^{50}$ Henri Bergson, La Pensée et le mouvant (Paris: Alcan, 1934), 20. - tłum. A.D.

${ }^{51}$ Ten przykład (którego wadą jest psychologizowanie pojęcia dostępności) pochodzi ze słynnego podręcznika:

George Edward Hughes i Maxwell John Cresswell, An Introduction to Modal Logic (London: Methuen, 1972), 77-78.

${ }^{52} \mathrm{Eco}$, Lector in fabula, 197.
} 
Wszystko to musi zostać pogłębione i usystematyzowane, ale nie jest pewne, czy uda się nam ściśle zdefiniować genetyczne reguły dostępności w ramach logiki aletycznej (opartej na kategoriach możliwego, koniecznego, warunkowego lub niemożliwego). Być może te kategorie nie są najodpowiedniejsze dla genezy? A może trzeba się będzie odwołać do innych rodzajów logiki modalnej, które zachowują podobną strukturę, ale nadają operatorom inne znaczenie możliwości i konieczności, aby odzwierciedlić kategorie etyczne (dopuszczalne, zakazane, obowiązkowe) lub aksjologiczne (dobro, zło, neutralne, niezależnie od treści zawartych w tych kryteriach), to znaczy do logik czasowych (odtąd, czasami, nigdy) liniowych lub rozgałęzionych? Być może wszystko to okaże się zbyt statyczne i trzeba będzie się odwołać do logiki dynamicznej lub logiki rozmytej, które w chwili obecnej usiłują określić swoje miejsce?

Jednak zanim przejdziemy dalej, konieczne wydaje się zbadanie, co mogłyby nam dać podstawowe ramy aletyczne, co dałoby się zaadaptować. Ściślej mówiąc, chodzi oniezbędne adaptacje, które pozwolą nam lepiej zrozumieć specyfikę naszego przedmiotu.

\section{Świat(y)}

Jak widać, odwołanie do pojęcia możliwych światów otwiera pewne perspektywy. Dzięki praktyce możemy się dowiedzieć, czy taki sposób stawiania problemów okaże się owocny i czy wpłynie na sposób myślenia o naszym przedmiocie, a także czy może mieć wpływ, marginalny lub głeboki, na naszą praktykę codzienną.

Nieprzekonani sądzą, że ma potrzeby przejmowania en bloc całego systemu. Pojęcie można zdekomponować. Genetyka może odłożyć na bok semantykę możliwych światów i (być może?) także obejść się bez pojęcia światów „fikcyjnych”, uznawanych przez niektórych za sprzeczne, ale nie może się obejść bez pojęcia „świata”, tzn. ekstensjonalnego wymiaru genezy, którego nasza praca nie powinna zaniedbywać, a zwłaszcza „światów”, w liczbie mnogiej ${ }^{53}$, jako korelatu pojęcia „fabrication de monde”, „worldmaking”, by posłużyć się w tym miejscu raz jeszcze tytułem dzieła Nelsona Goodmana ${ }^{54}$. Według niego, co znaznaczyliśmy już wcześniej, nie istnieje świat dany, istnieją jedynie światy skonstruowane ${ }^{55}$, włączywszy doń także ten, który uważamy za rzeczywistość. Taki radykalny konstruktywizm nie ma na celu niezadowolenia krytyki genetycznej, zwłaszcza że można powiedzieć, że w rzeczywistości jest to rekonstruktywizm lub radykalny rewizjonizm („Dla nas budowanie świata zawsze dokonuje się w oparciu o światy, którymi już dysponujemy; robić to przerobičn"56). Znajdujemy również, omówione w Manières de faire des mondes, znane mechanizmy genetyczne: kompozycję i dekompozycję, selektywne wzmocnienie, reorganizację, usuwanie i dodawanie, deformację.

\footnotetext{
${ }^{53}$ Niezależnie od tego, czy akceptujemy koncepcję możliwego bronioną przez Leibniza, jej obrona wprowadza ideę wielości światów reprezentowanych, zarazem odrębnych i matematycznie skoordynowanych.

${ }^{54}$ Nelson Goodman, Ways of Worldmaking, w języku francuskim: Manières de faire des mondes, tłum. MarieDominique Popelard (Nîmes: Éditions Jacqueline Chambon, 1992).

${ }^{55}$ Zob. zwłaszcza Goodman, Of Mind and Other Matters, 125. Malgré la différence de force illocutoire entre les verbes " construire » et "stipuler ", il ne semble pas pertinent, du point de vue génétique, de maintenir une distinction entre les mondes construits de Goodman et les mondes stipulés de Kripke. La stipulation d'un monde suppose évidemment une construction, fût-elle embryonnaire. Mais la construction de mondes (activité dans laquelle nous sommes perpétuellement engagée, que nous en ayons conscience ou non) ne suppose-t-elle pas une stipulation implicite (soit un monde tel que...) ? C'est en tout cas ainsi qu'on est obligé d'analyser la production d'une œuvre.

${ }^{56}$ Goodman, Manières de faire des mondes, 15 (przekład zmodyfikowany).
} 
Jeśli chodzi o wstępne założenia tej rozprawy („Bez pretensji do przejęcia mocy bogów lub innych twórców świata, [...] chcę zilustrować i skomentować kilka procesów, które składają się na wymyślanie światów" ${ }^{57}$ ), genetycy mogliby to zrobić sami, zarówno jeśli chodzi o wymyślanie światów ograniczonych - napotykanych w rękopisach - czy efektywną konstrukcję rozległych światów typu goodmanowskiego ${ }^{58} . \mathrm{Z}$ ich znajomością, pogłębioną mechanizmami genezy, genetycy z pewnością mają coś do powiedzenia w tej sprawie.

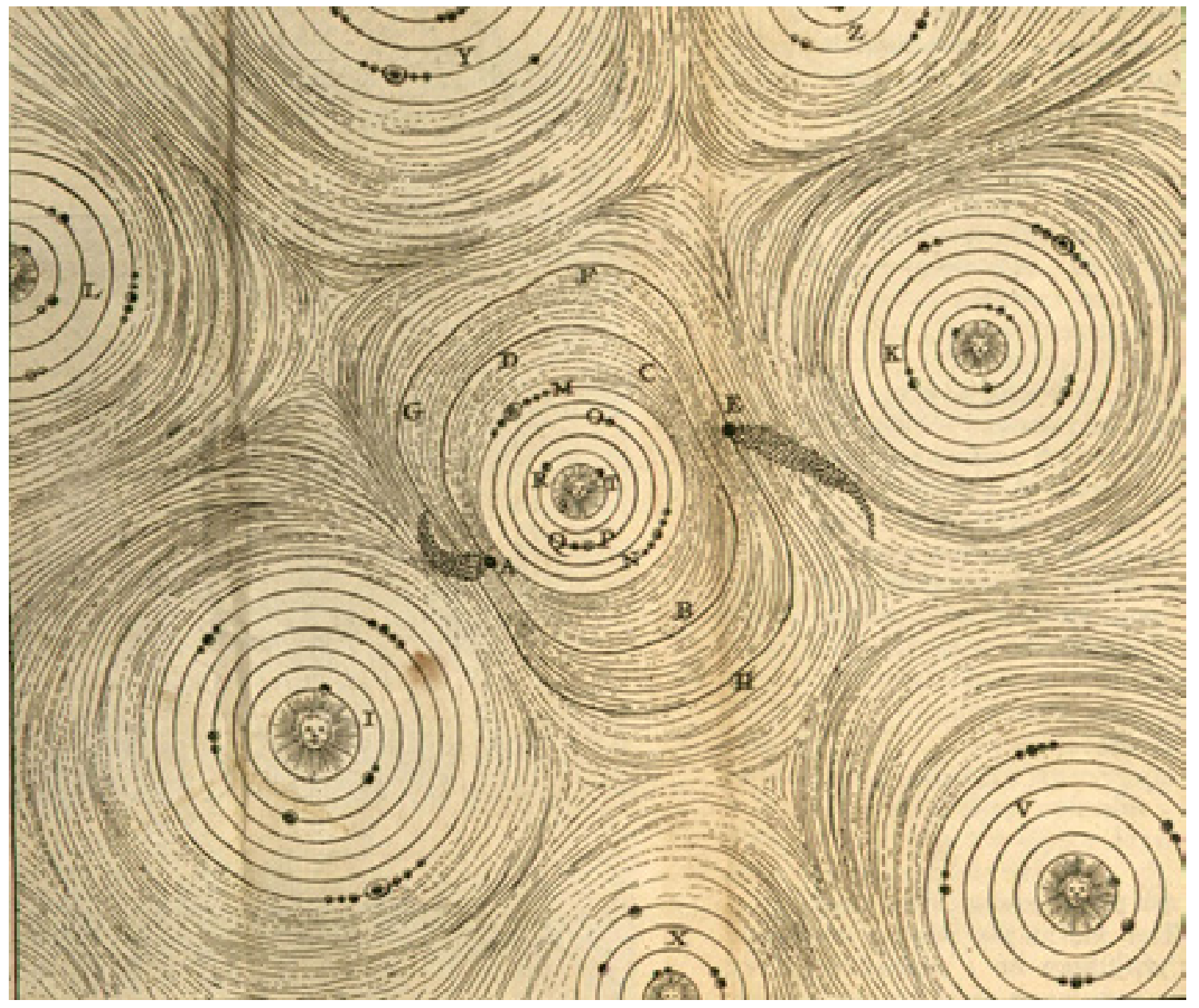

Ilustracja 4. Z dzieła Nicolasa Biona L’usage des globes célestes et terrestres et des sphères suivant les différents systèmes du monde (1699)

\section{Apendyks terminologiczny: diegeza/świat(y) - opowiadanie/fikcja}

Jedna kwestia z zakresu słownictwa bez wątpienia zasługuje na podniesienie. Dlaczego nie używać ustalonego narratologicznie terminu „diegesis”, jeśli „księgi przeznaczeń” Leibniza są „opowiadaniami” i ich „przeznaczenia”, ich „światy” zdają się pasować do tego, co Genette za Souriau nazywa „diegezą" ${ }^{99}$ ? Wpierw trzeba zauważyć, że to pojęcie jest właściwie stosunkowo rzadko wykorzystywane w klasycznej narratologii, być może dlatego, że jest zatarte przez werbalną bliskość

\footnotetext{
${ }^{57}$ Goodman (przekład zmodyfikowany).

${ }^{58}$ To znaczy, co zwykle zwane jest „wizjami świata”, nazwą mylną według Goodmana, ponieważ sugeruje ona istnienie świata ubprzedniego wobec wizji i możliwego do oddzielenia od nich.

${ }^{59}$ Eugène Souriau, „La structure de l'univers filmique et le vocabulaire de la filmologie”, Revue internationale de Filmologie, nr 7-8 (1951): 231-240.
} 
Arystotelesowskiej „diegesis”, ale przede wszystkim dlatego, że jest strukturalnie marginalne w porównaniu z parą „fabuła” $i$,narracja” (podobnie jak referent pozostaje marginalny w lingwistyce saussure'owskiej w stosunku do pary „signifié” i „signifiant”) i czasami mylone z historią ${ }^{60}$.

Znaczenie przedstawione $\mathrm{w}$ indeksie terminologicznym Figures II (,świat czasoprzestrzenny określony przez opowiadanie”) różni się istotnym niuansem od definicji Souriau („wszystko, co ma się wydarzyć, zgodnie z fikcją przedstawioną w filmie; wszystko co fikcja implikuje, gdyby założyć, że jest to prawdą"61). Jak trafnie zauważa Genette w przedmowie do Logique des genres littéraires Käte Hamburger:

nie można badać fikcyjnej narracji jednocześnie jako narracji i jako fikcji: zwrot „jako narracja” narratologii z definicji oznacza, że udajemy akceptację istnienia [...] „przed” opowieścią, historii do opowiedzenia; zwrot ,jako fikcja” u Käte Hamburger, wprost przeciwnie, implikuje odrzucenie tej hipotezy ${ }^{62}$.

Genette w Figures II rozważa diegezę, począwszy od narracji ${ }^{63}$, która ją oznacza w całej historii, tak jak signifiant oznacza referent przez jego signifié (bez potrzeby pytania, czy ta historia i diegeza istniały w opowiadaniu, czy też są przez nie generowane). Z drugiej strony, diegezy u Souriau nie da się oddzielić od fikcjonalności, z którą jest związana przez relację inferencji („wszystko, co ma się wydarzyć, zgodnie z fikcją [...], wszystko, co ta fikcja mogłaby implikować”). Jest ona przedmiotem silnej modalizacji („Zgodnie z fikcją [...], jeśli założymy, że to prawda”). Idee modalizacji i inferencji, praktykowane na podstawie jednostek funkcjonalnych, mają kapitalne znaczenie dla teorii fikcji, a jeszcze większe dla teorii genetycznej, ale widać wyraźnie, jak dwuznaczny jest w tym względzie termin „diegeza”. To dlatego został on oddalony w niniejszym artykule i dlatego użyto terminu „świat”, bez wątpienia jeszcze bardziej niejednoznacznego, ale za to powszechnie rozumianego.

Poza tradycją filozoficzną i logiczną ${ }^{64}$ termin „świat” jest powszechnie stosowany w wielu innych kontekstach, w tym w krytyce literackiej. Mówimy więc, z pewnym wątpieniem, o „świecie Balzaca" (czy Verlaine’a lub Szekspira). Skądinąd teoretycy, tacy jak Ingarden czy Lotman, używali tego słowa w perspektywie fenomenologicznej lub semiologicznej, aby wyznaczyć zasadę wewnętrznej spójności ${ }^{65}$. Mam nadzieję, iż udało mi się wykazać, że biorąc pod uwagę wielość światów alternatywnych, można otworzyć zróżnicowane punkty widzenia.

\section{Przełożył Adam Dziadek}

\footnotetext{
${ }^{60}$ Genette uznaje, że jego dwuznaczne sformułowanie „Discours du récit” w Figures III (Paris: Éditions du Seuil, 1972) jest po części odpowiedzialne za tę niejasność. Próbował to wyjaśnić w Palimpsestes (Paris: Éditions du Seuil, 1982), gdzie wyraźnie rozróżniał historię, „następstwo zdarzeń i/lub akcji” oraz „diegesis”, „świat, w którym ta historia ma miejsce” (s. 342), i ponownie w Les Nouveaux Discours du récit (Paris: Éditions du Seuil, 1983).

${ }^{61}$ Souriau, „La structure de l'univers filmique et le vocabulaire de la filmologie”, 240.

${ }^{62}$ Gérard Genette, Figures II (Paris: Éditions du Seuil, 1986), 13.

${ }^{63}$ Słowo „narracja” [„récit”] należy rozumieć w szerokim sensie: fragmenty opisowe mają oczywiście funkcję desygnującą świat czasoprzestrzenny, równorzędny, a nawet nadrzędny wobec tych, które pojawiają się w partiach czysto narracyjnych. Zauważmy, że w dziedzinie filmu, w której sytuuje się Souriau, rozróżnienie narracja - opis niekoniecznie jest istotne.

${ }^{64}$ Saul Kripke stwierdza, że nazwa „światy możliwe” jest przyczyną „terminologicznego wypadku” i równie dobrze można ją zastąpić nazwami „możliwe stany świata” lub „sytuacje kontrafaktyczne”, czy też „możliwe historie świata". Kripke, La Logique des noms propres (Naming and Necessity), 171.

${ }^{65}$ Zob. analizę Ronen, Possible Worlds in Literary Theory, 95-107.
} 


\section{Bibliografia}

Becker, Colette. „Cela «s'établira en écrivant» (Zola)". W Émile Zola, La Fabrique des Rougon-Macquart. Édition des dossiers préparatoires. Opracowane przez Colette Becker przy współpracy Véronique Lavielle. T. 3, 210-212. Paris: Honoré Champion, 2006.

Bergson, Henri. La Pensée et le mouvant. Paris: Alcan, 1934.

Biasi, Pierre-Marc de. „L'analyse des manuscrits et la genèse de l'œuvre". W Encyclopaedia Universalis. Vol. Symposium, 466-476. Paris: Bordas, 1985.

Bellemin-Noël, Jean. „Reproduire le manuscrit, présenter les brouillons, établir un avanttexte". Littérature, nr 28 (1977), 3-18.

Collière, Christine. „Illustrating the Sylvie and Bruno Books: the Collaboration of Lewis Carroll and Harry Furniss". Recto Verso, nr 3, www.revuerectoverso.com/spip.php?article90 (dostęp: 30.05.2020).

Doležel, Lubomir. „Extensional and Intensional Narrative Worlds". Poetics, nr 8 (1979), 193211.

---. Heterocosmica. Fiction and Possible Worlds. Baltimore: The Johns Hopkins University Press, 1998.

Eco, Umberto. The Limits of Interpretation. Bloomington: Indiana University Press, 1994.

---. Lector in Fabula ou la Coopération interprétative dans les textes narratifs. Paris: Grasset, 1985.

---. Lector in fabula. Współdziałanie $w$ interpretacji tekstów narracyjnych. Przetłumaczone przez Piotr Salwa. Warszawa: PIW, 1979.

Ferrer, Daniel. „L'écriture et l'accident”. W Critique génétique: concepts, méthodes, outils. Zredagowane przez Olga Anokhina i Sabine Pétillon, 5-19. Paris: IMEC éditeur, 2009; seria „Inventaires”.

---. „Le matériel et le virtuel: du paradigme indiciaire à la logique des mondes possibles”. W Pourquoi la critique génétique? Méthodes, théories. Zredagowane przez Michel Contat i Daniel Ferrer, 11-30. Paris: CNRS Éditions, 1998.
---. „La toque de Clementis: rétroaction et rémanence dans les processus génétiques”. Genesis, nr 6 (1994), 93-106.

---. „Peut-on parler de métalepse génétique?”. W Métalepses: Entorses au pacte de représentation. Zredagowane przez John Pier i Jean-Marie Schaeffer, 109-119. Paris: Éditions de l'École des Hautes Études en Sciences sociales, 2005.

Genette, Gérard. Figures II. Paris: Éditions du Seuil, 1986.

---. Figures III. Paris: Éditions du Seuil, 1972.

---. Palimpsestes. Paris: Éditions du Seuil, 1982.

---. Les Nouveaux Discours du récit. Paris: Éditions du Seuil, 1983.

---. „Quelques remarques sur le couple énonciationgenèse”. Texte, nr 27/28 (2000), 8-23.

Goodman, Nelson. Faits, fictions et predictions. Paris: Éditions de Minuit, 1985.

---. Manières de faire des mondes. Przetłumaczone przez Marie-Dominique Popelard. Nîmes: Éditions Jacqueline Chambon, 1992.

---. Of Mind and Other Matters. Cambridge: Harvard University Press, 1984.

Grésillon, Almuth. „Les variantes de manuscrits: critères et degrés de pertinence". W La Publication de manuscrits inédits. Zredagowane przez Louis Hay i Winfried Woesler, 179-189. Berne: Peter Lang Verlag, 1979.

Hay, Louis. La Littérature des écrivains. Questions de critique génétique. Paris: José Corti, 2002.

---. „ «Le texte n'existe pas». Réflexions sur la critique génétique”. Poétique, nr 62 (1985), 147-158.

Hughes, George Edward, Cresswell, Maxwell John. An Introduction to Modal Logic. London: Methuen, 1972.

Kerbrat-Orecchioni, Catherine. „Le texte littéraire: non-référence, auto-référence ou référence fictionnelle". Texte (1982), 27-49. 
Kripke, Saul. La Logique des noms propres (Naming and Necessity). Paris: Éditions de Minuit, 1982.

Lebrave, Jean-Louis. „La genèse de «La Chambre claire»". Genesis, nr 19 (2002), 79-107.

Leibniz, Gottfried Wilhelm. Teodycea: o dobroci Boga, wolności człowieka i pochodzeniu zła. Przetłumaczone przez Małgorzata Frankiewicz i Jerzy Kopania. Warszawa: Wydawnictwo Naukowe PWN, 2001.

Lewis, David. Counterfactuals. Cambridge: Harvard University Press, 1973.

Pavel, Thomas. Univers de la fiction. Paris: Éditions du Seuil, 1988.

Possible Worlds in Humanities, Arts and Sciences, Proceedings of Nobel Symposium 65. Zredagowane przez Sture Allén. Berlin, New York: Walter de Gruyter, 1989.

Proust, Marcel. À la recherche du temps perdu, III. Paris: Gallimard, coll. „Bibliothèque de la Pléiade", 1954.

Ronen, Ruth. Possible Worlds in Literary Theory. Cambridge: Cambridge University Press, 1994.

Ryan, Marie-Laure. Possible Worlds, Artificial Intelligence and Narrative Theory. Bloomington: Indiana University Press, 1991.

Souriau, Eugène. „La structure de l'univers filmique et le vocabulaire de la filmologie". Revue internationale de Filmologie, nr 7-8 (1951): 231-240.

Stendhal. CEuvres romanesques completes. Zredagowane przez Yves Ansel, Philippe Berthier i Xavier Bourdenet. Paris: Gallimard, 2007.

Veyne, Paul Comment on écrit l'histoire, suivi de Foucault révolutionne l'histoire. Paris: Éditions du Seuil, 1979.

Wright, Georg Henrik von. Causality and Determinism. New York: Columbia University Press, 1974. 


\title{
SŁOWA KLUCZOWE:
}

\section{krytyka genetyczna}

\author{
L O G I K A
}

\begin{abstract}
ABSTRAKT:
Krytyka genetyczna nie może pomijać ekstensjonalnego wymiaru genezy. Wiele korzyści mogłaby jej przynieść idea świata, bez wątpienia bardziej przydatna niż pojęcie diegesis, ponieważ pozwoliłoby to zrozumieć wielość światów ustanowionych. Przyjmując rozróżnienie światów tekstowych i światów fikcyjnych, możemy się wesprzeć logiką światów możliwych, aby spróbować wyjaśnić status światów, zarazem prawdziwych i wirtualnych, stworzonych w genezie, oraz aby zdefiniować reguły dostępności, które kierują relacjami między tymi światami.
\end{abstract}




\title{
ŚWIATY FIKCYJNE
}

\author{
światy możliwe
}

\section{NOTA O AUTORZE:}

Daniel Ferrer - dyrektor badań w l'ITEM (CNRS-ENS). Opublikował m.in. Poststructuralist Joyce (wraz z Derekiem Attridgem, Cambridge University Press, 1984), Virginia Woolf and the Madness of Language (Routledge, 1990), L'Écriture et ses doubles: genèse et variation textuelle (z Jeanem-Louis Lebrave'em, CNRS Éditions, 1991), Ulysse à l'article: Joyce aux marges du roman (wraz z Claude'em Jacquetem i André Topią, Du Lérot, 1992), Genèses du roman contemporain: Incipit et entrée en écriture (z Bernhild Boie, CNRS Éditions, 1993), Writing its own wrunes for ever: Essays in Joycean Genetics (z Claude'em Jacquetem, Du Lérot, 1998), Pourquoi la critique génétique? Méthodes, théories (z Michelem Contatem, CNRS Éditions, 1998), Bibliothèques d'écrivains (z Paolo D’Iorio, CNRS Éditions, 2001), Genetic Criticism: Texts and Avant-textes (z Jedem Deppmanem i Michaelem Grodenem, Pennsylvania University Press, Philadelphia 2004), La Textologie russe (z Andreiem Mikhailovem, CNRS Éditions, 2007). Wspólnie z Vincentem Deanem i Geertem Lernoutem przygotowuje edycję Finnegans Wake Notebooks at Buffalo (Brepols, 12 tomów opublikowanych, 48 ma się ukazać). W języku polskim ukazał się jego tekst napisany wspólnie z Nicolasem Doninem: Autor(zy) i aktorzy genezy (tłum. Dorota Jarząbek-Wasyl, „Wielogłos” 2019, nr 1, s. 37-63). 